\title{
Nodulation Gene Mutants of Mesorhizobium loti R7A-nodZ and nolL Mutants Have Host-Specific Phenotypes on Lotus spp.
}

\author{
Patsarin Rodpothong, ${ }^{1,2}$ John T. Sullivan, ${ }^{1,2}$ Kriangsak Songsrirote, ${ }^{3}$ David Sumpton, ${ }^{3}$ \\ Kenneth W. J.-T. Cheung, ${ }^{3}$ Jane Thomas-Oates, ${ }^{3}$ Simona Radutoiu, ${ }^{2,4}$ Jens Stougaard, ${ }^{2,4}$ and \\ Clive W. Ronson ${ }^{1,2}$
}

${ }^{1}$ Department of Microbiology and Immunology, University of Otago, Dunedin, New Zealand; ${ }^{2}$ Centre for Carbohydrate Recognition and Signaling, University of Aarhus, Aarhus, Denmark; ${ }^{3}$ Department of Chemistry, University of York, York, United Kingdom; and ${ }^{4}$ Department of Molecular Biology, University of Aarhus, Aarhus, Denmark

Submitted 1 June 2009. Accepted 14 July 2009.

\begin{abstract}
Rhizobial Nod factors induce plant responses and facilitate bacterial infection, leading to the development of nitrogenfixing root nodules on host legumes. Nodule initiation is highly dependent on Nod-factor structure and, hence, on at least some of the nodulation genes that encode Nod-factor production. Here, we report the effects of mutations in Mesorhizobium loti R7A nodulation genes on nodulation of four Lotus spp. and on Nod-factor structure. Most mutants, including a $\Delta$ nodS $\Delta$ nolO double mutant that produced Nod factors lacking the carbamoyl and possibly $N$ methyl groups on the nonreducing terminal residue, were unaffected for nodulation. R7A $\Delta$ nodZ and R7A $\Delta$ nolL mutants that produced Nod factors without the (acetyl)fucose on the reducing terminal residue had a host-specific phenotype, forming mainly uninfected nodule primordia on $\mathrm{Lo}$ tus filicaulis and $L$. corniculatus and effective nodules with a delay on L. japonicus. The mutants also showed significantly reduced infection thread formation and Nin gene induction. In planta complementation experiments further suggested that the acetylfucose was important for balanced signaling in response to Nod factor by the $L$. japonicus NFR1/NFR5 receptors. Overall the results reveal differences in the sensitivity of plant perception with respect to signaling leading to root hair deformation and nodule primordium development versus infection thread formation and rhizobial entry.
\end{abstract}

The establishment of a successful Rhizobium-legume symbiosis requires an intricate molecular communication involving recognition of signaling molecules produced by both partners. The process of nodule organogenesis is initiated by compatible rhizobia that produce lipochito-oligosaccharide signaling molecules known as Nod factors (NF). Host-specificity in the symbiosis is manifested both by specific flavonoids released by the host legume to induce NF production in compatible rhizobia and by the specific NF produced that are recognized by the compatible host. Early NF-induced responses include ion fluxes, calcium spiking, root hair deformation, cortical cell di-

Corresponding author: Clive Ronson; Telephone: +64 3479 7701; Fax: +64 3479 8540; E-mail: Clive.Ronson@ otago.ac.nz

* The $\boldsymbol{e}$-Xtra logo stands for "electronic extra" and indicates that four supplementary tables and one supplementary figure are published online. Also, Figures 1 and 4 appear in color online. vision, and induction of early nodulin genes. NF are also required for the formation of infection threads (Spaink 2000; Geurts et al. 2005; Oldroyd and Downie 2008). The plant NF receptor is possibly a multisubunit complex comprising at least two receptor-like kinases with extracellular LysM domains (NFR1 and NFR5 in Lotus japonicus; NFP, LYK3, and possibly other LYK proteins in Medicago truncatula), because mutants defective in NFR1, NFR5, and NFP do not exhibit any NF responses (Amor et al. 2003; Limpens et al. 2003; Madsen et al. 2003; Radutoiu et al. 2003). It has been suggested that there may be two distinct NF-induced events, a low-affinity "signaling" event required for root hair curling and primordium induction and a high-stringency "entry" event (Ardourel et al. 1994; Riely et al. 2006). It is not currently known if these events are mediated by the same or different NF receptor complexes. However, recent evidence suggests that, in $M$. truncatula, LYK3 in conjunction with NFP acts as the entry receptor while NFP in conjunction with another LYK protein acts as the signaling receptor (Smit et al. 2007).

Mesorhizobium loti is the natural microsymbiont of Lotus spp. The genes required for nodule formation and nitrogen fixation in $M$. loti R7A are located on a 502-kb chromosomally located transferable element known as a symbiosis island, which was recently renamed ICEMlSym ${ }^{\mathrm{R} 7 \mathrm{~A}}$ (Sullivan et al. 1995; Sullivan and Ronson 1998; Ramsay et al. 2006). Sequence analysis of ICEMlSym ${ }^{\mathrm{R} 7 \mathrm{~A}}$ revealed that the genes necessary to produce the complete NF are arranged in seven operons, each preceded by a conserved DNA motif known as a nod box (Sullivan et al. 2002). An eighth nod box is found in front of a regulatory gene required for the expression of a type IV secretion system (Sullivan et al. 2002; Hubber et al. 2004). Expression of the nodulation genes is induced through the binding of the transcriptional activator NodD to the nod box (Rostas et al. 1986; Fisher and Long 1993). ICEMlSym ${ }^{\mathrm{R} 7 \mathrm{~A}}$ carries two copies of the nodD gene, nodD1 and nodD2.

The structures of NF produced by several $M$. loti strains, including NZP2238, the parental strain of R7A, have been determined. The "complete" NF produced by both strains is an Nacetylglucosamine pentasaccharide. The nonreducing residue is $\mathrm{N}$-methylated and $\mathrm{N}$-acylated with cis-vaccenic acid (C18:1) or stearic acid (C18:0) and carries a carbamoyl group, and the reducing terminal residue carries a 4- $O$-acetylfucosyl residue (López-Lara et al. 1995; Niwa et al. 2001) (Supplementary Fig. S1). The importance of the terminal decorations for nodulation of various host Lotus spp. has not been widely studied. 
Expression of Bradyrhizobium japonicum nodZ in Rhizobium leguminosarum bv. viciae RBL5560 allowed the strain to nodulate L. japonicus, normally a nonhost, but with limited efficacy. Addition of the M. loti nolL gene into RBL5560::nodZ improved nodulation kinetics to closer to those obtained with M. loti R7A (Pacios-Bras et al. 2000). The nodZ gene product adds the fucosyl residue to the reducing terminal residue of the NF (Mergaert et al. 1996; Quesada-Vincens et al. 1997) and the nolL gene product adds the 4-O-acetyl group to the fucosyl residue (Berck et al. 1999; Corvera et al. 1999). Hence, this study indicated the importance of the modifications to the reducing terminal residue for host-specificity in L. japonicus. In contrast, Shibata and associates (2005) reported that a nolL mutant of $M$. loti MAFF303099 nodulates L. japonicus normally. Several other studies have shown that various NF decorative substitutions can have host-specific effects, presumably reflecting differing specificities of the legume NF receptors. For example, strain RBL5560 carrying the nodZ gene also acquired the capacity to induce uninfected nodule-like structures in several other incompatible hosts (López-Lara et al. 1996). A nolL mutant of $M$. loti NZP2037 lost the ability to nodulate $L$. pedunculatus but still nodulated $L$. corniculatus (Scott et al. 1996). An R. etli nolL mutant showed reduced nodulation of some hosts but not others (Corvera et al. 1999). Transfer of the Rhizobium sp. NGR234 nolL gene into Sinorhizobium fredii USDA257 extended its host range to include Calopogonium caeruleum, Leucaena leucocephala and Lotus halophilus (Berck et al. 1999).

Two legume species, L. japonicus and Medicago truncatula, have been chosen as models to investigate legume biology due to their small genome size and other favorable characteristics. L. japonicus is closely related to the tetraploid pasture species L. corniculatus (birdsfoot trefoil) and it is also cross-fertile with the diploid species $L$. filicaulis and L. burttii. Genetic maps and recombinant inbred lines derived from crosses of these species with L. japonicus Gifu and intraspecific crosses between L. japonicus ecotypes Gifu and Miyakojima MG-20 provide powerful tools for efficient genetic analysis in Lotus spp. (Hayashi et al. 2001; Kawaguchi et al. 2005; Sandal et al. 2006). Therefore, knowledge of the effects of NF structure on host specificity coupled with approaches such as quantitative trait loci analysis and map-based cloning could contribute to our understanding of the structure and function of NF receptors.

In this study, we have systematically mutagenized the nod genes present on ICEMlSym ${ }^{\mathrm{R} 7 \mathrm{~A}}$ and assessed the symbiotic properties of the strain R7A mutants on four Lotus spp. Only three mutants had a clean $\mathrm{Nod}^{-}$phenotype, while the nodZ and nolL mutants displayed host-specific phenotypes. Our results are consistent with a two-phase model of NF perception, one phase involving root hair deformation and primordium induction and the other infection thread formation and entry.

\section{RESULTS}

\section{Mutants in most Mesorhizobium loti nod genes}

do not have an overt symbiotic phenotype.

Mutants with markerless in-frame deletions in 12 of the nodulation genes identified on ICEMlSym ${ }^{\mathrm{R} 7 \mathrm{~A}}$ (all nodulation genes except nodI, nodJ, noeJ, and noeK) plus two double mutants (R7A $\Delta$ nodS $\Delta$ nolO and R7A $\Delta$ nodD1 1 nodD2) were constructed and their symbiotic properties were assessed on at least two of the four species L. corniculatus, L. japonicus Gifu, L. filicaulis, and L. burttii (Table 1). Only strains R7A $\Delta$ nodA, R7A $\Delta$ nodC , and R7A $\Delta$ nodD1 $\Delta$ nodD2 failed to induce nodule formation. Strain R7A $\triangle$ nodA was complemented to $\mathrm{Nod}^{+}$by pJS01 that contains only nodA, indicating that the $\triangle$ nodA mutation did not alter expression of the downstream nodC gene. Mutants defective in $\operatorname{nodD} 2, \operatorname{nod} M, \operatorname{nodB}, \operatorname{nod} S$, and $\operatorname{nolO}$ formed nitrogen-fixing nodules on all Lotus spp. tested, with the same nodulation kinetics as wild-type R7A, as did a $\Delta$ nodS $\Delta$ nolO double mutant. Strain R7A $\Delta$ nodD1 induced nitrogen-fixing nodules on $L$. japonicus and $L$. corniculatus with a slight delay (3 days) in the onset of nodulation (data not shown). In contrast, mutants in nolL (R7A $\Delta$ nolL) and in genes of the nodZ operon (R7A $\Delta$ nodZ, R7A $\Delta$ noeL, and R7A $\Delta$ nolK) showed a host-specific phenotype, forming effective nodules on L. burttii and L. japonicus Gifu after a delay but mainly uninfected nodules on at least one other host (see below).

To determine if the efficiency of nodulation was impaired by particular mutations, coinoculation studies of selected mutants

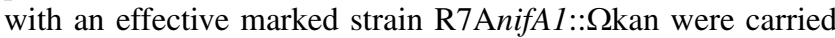
out on L. japonicus (Table 2). A mixed inoculum of R7A and R7AnifA $1:: \Omega$ kan showed an average of 40 and $55 \%$ of nodules

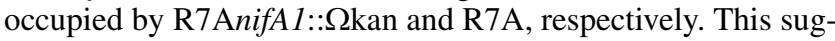
gests that R7AnifA $1:: \Omega$ kan was able to invade plant cells and occupy nodules as efficiently as R7A. In contrast, the $\Delta$ nodB, $\Delta$ nodZ, and $\Delta$ noll strains displayed severely impaired competitive ability because only an average of 3 and $5 \%$ of the nodules were occupied by R7A $\Delta$ nodB and R7A $\Delta$ nodZ, respectively, compared with an average of more than $80 \%$ of nodules

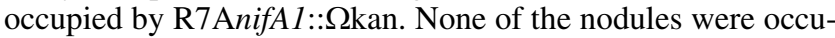
pied by strain R7A $\Delta$ nolL alone. The R7A $\Delta$ nodS, R7A $\Delta$ nolO,

Table 1. Nodulation phenotypes of Lotus spp. inoculated with Mesorhizobium loti nod gene mutants observed at week 4 postinoculation

\begin{tabular}{|c|c|c|c|c|}
\hline \multirow[b]{2}{*}{ Strain } & \multicolumn{4}{|c|}{ Nodulation phenotype on Lotus spp. ${ }^{\mathrm{z}}$} \\
\hline & L. japonicus & L. filicaulis & L. corniculatus & L. burttii \\
\hline R7A & $\mathrm{Inf}^{+} \mathrm{Ndv}^{+}$ & $\mathrm{Inf}^{+} \mathrm{Ndv}^{+}$ & $\mathrm{Inf}^{+} \mathrm{Ndv}^{+}$ & $\mathrm{Inf}^{+} \mathrm{Ndv}^{+}$ \\
\hline $\mathrm{R} 7 \mathrm{~A} \triangle \operatorname{nod} D 1$ & $\mathrm{Inf}^{+} \mathrm{Ndv}^{\mathrm{d}}$ & $\mathrm{Nd}$ & $\mathrm{Inf}^{+} \mathrm{Ndv}^{\mathrm{d}}$ & $\mathrm{Nd}$ \\
\hline R7A $\triangle$ nodD2 & $\mathrm{Inf}^{+} \mathrm{Ndv}^{+}$ & $\mathrm{Nd}$ & $\mathrm{Inf}^{+} \mathrm{Ndv}^{+}$ & $\mathrm{Nd}$ \\
\hline $\mathrm{R} 7 \mathrm{~A} \Delta$ nodD1 $1 \Delta$ nodD2 & $\mathrm{Inf}^{-} \mathrm{Ndv}^{-}$ & $\mathrm{Nd}$ & $\mathrm{Inf}^{-} \mathrm{Ndv}^{-}$ & $\mathrm{Nd}$ \\
\hline $\mathrm{R} 7 \mathrm{~A} \Delta \operatorname{nod} A$ & $\mathrm{Inf}^{-} \mathrm{Ndv}^{-}$ & $\mathrm{Nd}$ & $\mathrm{Inf}^{-} \mathrm{Ndv}^{-}$ & $\mathrm{Nd}$ \\
\hline $\mathrm{R} 7 \mathrm{~A} \Delta \operatorname{nod} B$ & $\operatorname{Inf}^{+} \mathrm{Ndv}^{+}$ & $\mathrm{Inf}^{+} \mathrm{Ndv}^{+}$ & $\mathrm{Inf}^{+} \mathrm{Ndv}^{+}$ & $\mathrm{Inf}^{+} \mathrm{Ndv}^{+}$ \\
\hline $\mathrm{R} 7 \mathrm{~A} \Delta \operatorname{nod} C$ & $\mathrm{Inf}^{-} \mathrm{Ndv}^{-}$ & $\mathrm{Inf}^{-} \mathrm{Ndv}^{-}$ & $\mathrm{Inf}^{-} \mathrm{Ndv}^{-}$ & $\mathrm{Inf}^{-} \mathrm{Ndv}^{-}$ \\
\hline $\mathrm{R} 7 \mathrm{~A} \Delta \operatorname{nod} M$ & $\mathrm{Inf}^{+} \mathrm{Ndv}^{+}$ & $\mathrm{Inf}^{+} \mathrm{Ndv}^{+}$ & $\mathrm{Inf}^{+} \mathrm{Ndv}^{+}$ & $\mathrm{Nd}$ \\
\hline R7A $\Delta \operatorname{nod} S$ & $\mathrm{Inf}^{+} \mathrm{Ndv}^{+}$ & $\mathrm{Nd}$ & $\mathrm{Inf}^{+} \mathrm{Ndv}^{+}$ & $\mathrm{Inf}^{+} \mathrm{Ndv}^{+}$ \\
\hline $\mathrm{R} 7 \mathrm{~A} \Delta$ nolO & $\mathrm{Inf}^{+} \mathrm{Ndv}^{+}$ & $\mathrm{Nd}$ & $\mathrm{Inf}^{+} \mathrm{Ndv}^{+}$ & $\mathrm{Inf}^{+} \mathrm{Ndv}^{+}$ \\
\hline R7A $\triangle$ nolO $\Delta$ nodS & $\mathrm{Inf}^{+} \mathrm{Ndv}^{+}$ & $\mathrm{Inf}^{+} \mathrm{Ndv}^{+}$ & $\mathrm{Inf}^{+} \mathrm{Ndv}^{+}$ & $\mathrm{Inf}^{+} \mathrm{Ndv}^{+}$ \\
\hline R7A $\triangle$ nodZ & $\mathrm{Inf}^{+} \mathrm{Ndv}^{\mathrm{d}}$ & $\mathrm{Inf}^{-} \mathrm{Ndv}^{\mathrm{d}}$ & $\mathrm{Inf}^{-} \mathrm{Ndv}^{\mathrm{d}}$ & $\mathrm{Inf}^{+} \mathrm{Ndv}^{+}$ \\
\hline R7A $\Delta$ nolL & $\mathrm{Inf}^{+} \mathrm{Ndv}^{\mathrm{d}}$ & $\mathrm{Inf}^{-} \mathrm{Ndv}^{\mathrm{d}}$ & $\mathrm{Inf}^{+} \mathrm{Ndv}^{\mathrm{d}}$ & $\mathrm{Inf}^{+} \mathrm{Ndv}^{+}$ \\
\hline $\mathrm{R} 7 \mathrm{~A} \Delta$ nolK & $\mathrm{Inf}^{+} \mathrm{Ndv}^{\mathrm{d}}$ & $\mathrm{Inf}^{-} \mathrm{Ndv}^{\mathrm{d}}$ & $\mathrm{Inf}^{+} \mathrm{Ndv}^{\mathrm{d}}$ & $\mathrm{Inf}^{+} \mathrm{Ndv}^{+}$ \\
\hline $\mathrm{R} 7 \mathrm{~A} \Delta$ noeL & $\mathrm{Inf}^{+} \mathrm{Ndv}^{\mathrm{d}}$ & $\mathrm{Inf}^{-} \mathrm{Ndv}^{\mathrm{d}}$ & $\mathrm{Inf}^{-} \mathrm{Ndv}^{\mathrm{d}}$ & $\mathrm{Inf}^{+} \mathrm{Ndv}^{+}$ \\
\hline
\end{tabular}

${ }^{\mathrm{z}} \mathrm{Inf}^{+}=$infected nodules, $\mathrm{Inf}^{-}=$uninfected nodules, $\mathrm{Ndv}^{+}=$normal nodule development, $\mathrm{Ndv}^{\mathrm{d}}=$ delayed nodule development, $\mathrm{Ndv}^{-}=\mathrm{no}$ nodule development, and $\mathrm{Nd}=$ not determined. 
and R7A $\Delta$ nodS $\Delta$ nolO strains were as competitive as wild-type R7A because an average of $68 \%$ of nodules formed on $L$. japonicus roots were occupied by the former strains whereas less than $30 \%$ of the nodules were occupied by R7AnifAl:: $\Omega$ kan. Similar results were obtained on L. filicaulis (data not shown).

The host-specific nodulation phenotype displayed by the $\Delta$ nolL and $\triangle$ nodZ mutants.

On L. filicaulis, R7A $\Delta$ nolL and R7A $\Delta$ nodZ both exhibited severely impaired nodulation. Nodule primordia were first observed on day 17 postinoculation. The majority of these structures did not develop further (Fig. 1). By day 38 postinoculation, a few effective nodules were observed on 5 and $15 \%$ of $L$. filicaulis plants inoculated with R7A $\Delta$ nodZ and R7A $\Delta$ nolL, respectively (Fig. 2A). In contrast, nodule primordia were first observed on roots of $L$. filicaulis inoculated with R7A on day 8 postinoculation, and all nodules were effective (Fig. 2A). Strain R7A $\Delta$ nodZ had a more severe phenotype on $L$. corniculatus compared with strain R7A $\Delta$ nolL (Fig. 2B). Nodule primordia induced by R7A $\Delta$ nodZ first appeared on day 14 postinoculation but only a small percentage developed into effective nodules and then only on $10 \%$ of the plants. In contrast, nodule primordia induced by R7A $\Delta$ nol $L$ were detected on day 9 postinoculation and $75 \%$ of the plants developed effective nodules. R7A $\Delta$ nodZ and R7A $\Delta$ nolL both formed effective nodules on all $L$. burttii and $L$. japonicus plants but nodule formation was delayed compared with plants inoculated with strain R7A. The delay was more pronounced for L. japonicus than L. burttii (Fig. $2 \mathrm{C}$ and $\mathrm{D})$. However, all plants nodulated by day 21 postinoculation and all nodules were pink in color, indicative of infection. The mutant strains were complemented with stable plasmid constructs pPR1 (nodZnoeLnolK) and pPR2 (nolL) and nodulation studies carried out on $L$. corniculatus. The nodulation kinetics of plants inoculated with strain R7A $\Delta$ nodZ/pPR1 were similar to those inoculated with the wild-type strain R7A. However, although strain R7A $\Delta$ nolL/pPR2 induced a higher number of

Table 2. Percentage occupancy of Lotus japonicus nodules inoculated with different Mesorhizobium loti strains $^{\mathrm{z}}$

\begin{tabular}{|c|c|c|c|}
\hline Inoculum & $\begin{array}{c}\text { R7AnifA } \\
\text { only }\end{array}$ & $\begin{array}{c}\text { R7A or } \\
\text { mutant } \\
\text { only }\end{array}$ & Mixed \\
\hline 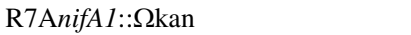 & 100 & 0 & 0 \\
\hline 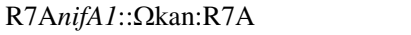 & $40 \pm 6$ & $55 \pm 4$ & $4 \pm 2$ \\
\hline 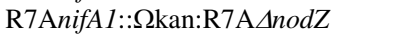 & $93 \pm 4$ & $3 \pm 3$ & $4 \pm 2$ \\
\hline 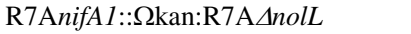 & $87 \pm 7$ & 0 & $13 \pm 7$ \\
\hline 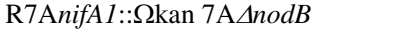 & $84 \pm 4$ & $5 \pm 5$ & $11 \pm 1$ \\
\hline 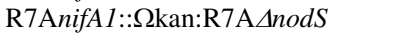 & $16 \pm 3$ & $68 \pm 6$ & $16 \pm 3$ \\
\hline 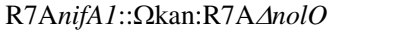 & $29 \pm 2$ & $68 \pm 6$ & $3 \pm 3$ \\
\hline 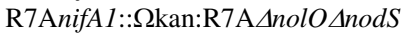 & $22 \pm 3$ & $68 \pm 12$ & $9 \pm 9$ \\
\hline
\end{tabular}

${ }^{\mathrm{z}}$ Values represent the mean percentage occupancy ( \pm standard error of the mean) of at least two experimental replicates.
A

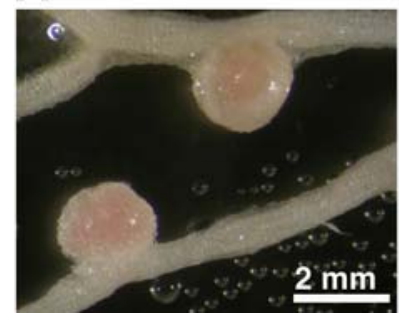

B

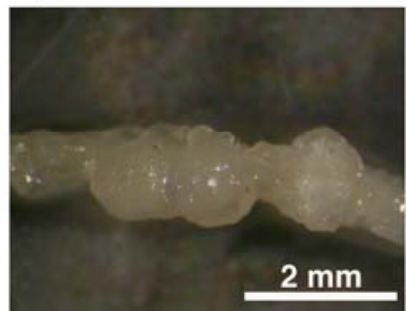

Fig. 1. A, Effective nodules formed by R7A and B, uninfected nodule primordia formed by R7A $\Delta$ nodZ on Lotus filicaulis roots at 4 weeks postinoculation. nodules than strain R7A $\Delta$ nolL, the onset of nodulation was still delayed (Fig. 2B).

\section{The $\Delta$ nolL and $\Delta$ nodZ mutants are defective}

for infection thread formation.

The abilities of R7A $\Delta$ nodZ and R7A $\Delta$ nolL to induce root hair deformation and to form infection threads were assessed on $L$. corniculatus and L. japonicus. Root hair branching, root hair tip swelling, and root hair curling were observed on both Lotus spp. inoculated with R7A $\Delta$ nodZ or R7A $\Delta$ nolL (data not shown). To allow infection thread visualization, plasmid pPR3
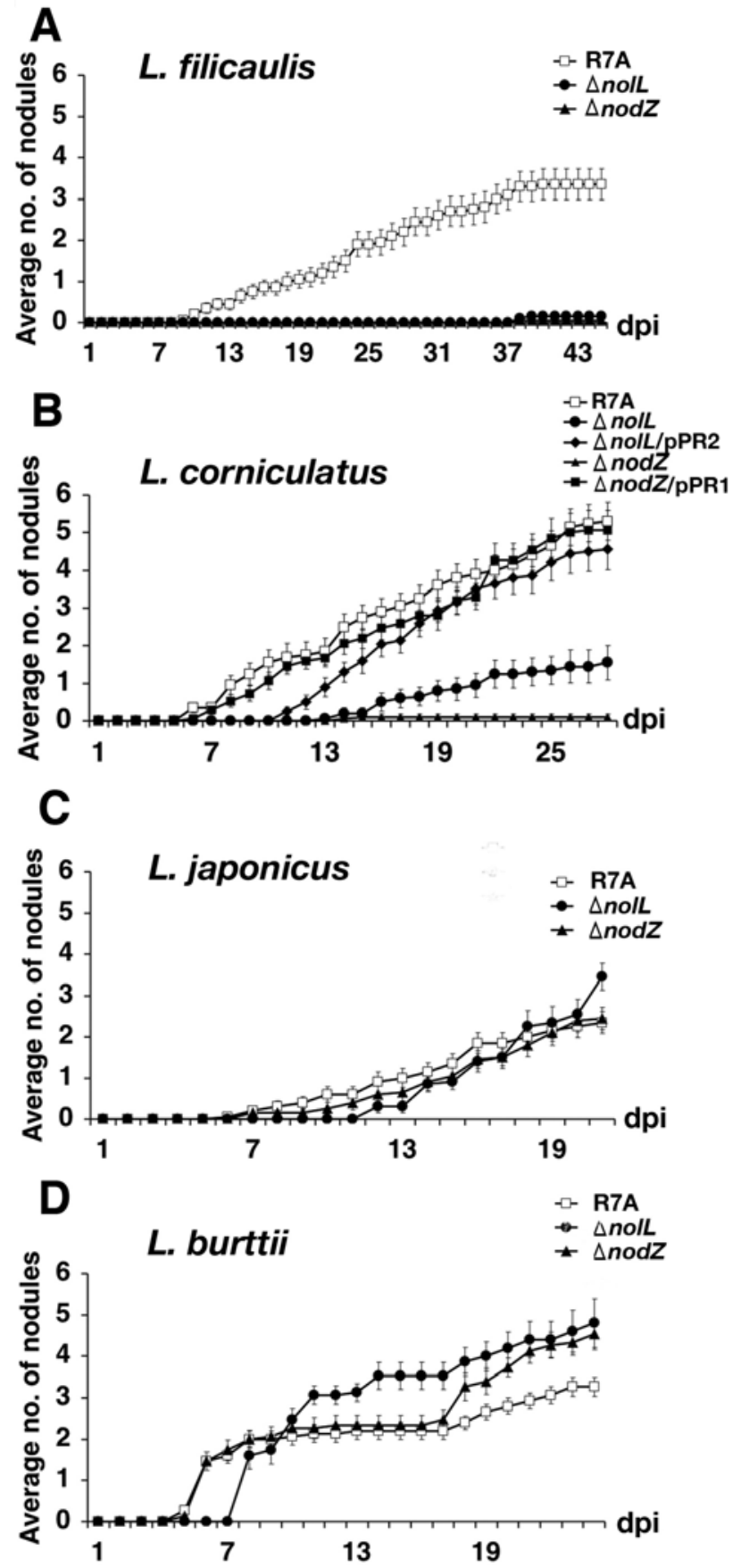

Fig. 2. Nodulation kinetics on A, Lotus filicaulis; B, L. corniculatus; $\mathbf{C}, L$. japonicus Gifu; and D, L. burttii inoculated with Mesorhizobium loti strains R7A, R7A 4 nolL, and R7A 4 nodZ. L. corniculatus inoculated with complemented strains R7A $\Delta$ nolL/pPR2 and R7A $\Delta$ nodZ/pPR1 are also shown in B. Twenty plants were used per strain per experiment. Error bars represent \pm standard error of the mean. Only nodules assessed as being infected on the basis of size and color were counted. 
that constitutively expresses enhanced green fluorescent protein (eGFP) was introduced into R7A, R7A $\Delta$ nodZ, and R7A $\Delta$ nolL. The number of infection threads formed by the mutants on $L$. japonicus seedlings was significantly reduced compared with the wild type, with R7A $\triangle$ nolL forming even fewer infection threads than R7A $\Delta$ nodZ (Fig. 3A). In L. corniculatus root hairs, R7A $\Delta$ nolL also displayed a delay in infection thread formation but infection thread numbers were not significantly different from the numbers formed by R7A at 10 days postinoculation (Fig. 3B). In contrast, infection thread formation by R7A $\Delta$ nodZ was markedly reduced (Fig. 3B).

Transmission electron microscopy performed on sections of 4-week-old $L$. japonicus and $L$. corniculatus nodules formed by R7A $\Delta$ nodZ and R7A $\Delta$ nolL revealed the presence of infection threads and infected plant cells containing bacteroids. White nodule primordia on $L$. corniculatus roots inoculated with R7A $\Delta$ nodZ were devoid of bacteroids (data not shown). Taken together, these results suggest that the delayed nodulation phenotype and the reduced nodulation competitiveness observed with R7A $\Delta$ nodZ may be due to the defect in infection thread formation.

\section{Acetylfucosylated NF are required for efficient NF signal transduction.}

Previous studies showed that expression of, or balanced signaling through, the Lotus Nfrl/Nfr5 receptors may influence perception of NF variants (Radutoiu et al. 2007). Therefore, in planta complementation of the non-nodulating $L$. japonicus nfrl and nfr5 mutants by Agrobacterium rhizogenes transformation was employed to determine if the acetylfucose decoration was involved in NF recognition by the NFR1/NFR5 receptors. The $n f r l$ and $n f r 5$ mutant plants were complemented by transformation with vectors containing the $L$. japonicus $N f r 1$ and Nfr5 genes, respectively, and the transformed hairy
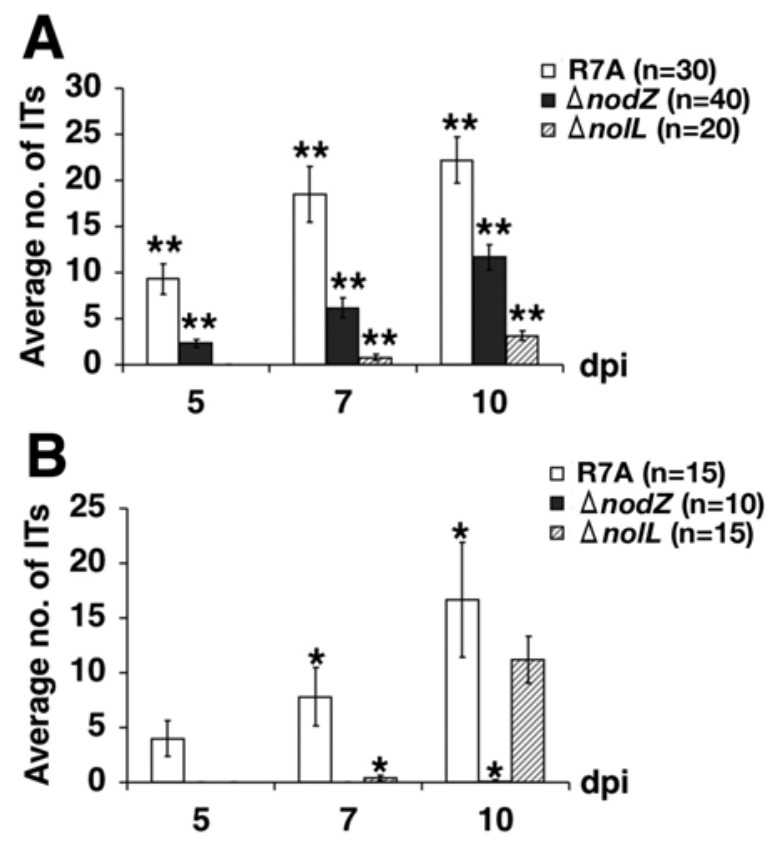

Fig. 3. Average number of infection threads formed in root hairs of $\mathbf{A}, L o$ tus japonicus and B, L. corniculatus by R7A, R7A AnodZ, and R7A AnolL containing pPR3 (nptII $\left.I_{\mathrm{p}}-g f p\right)$. Numbers of infection threads were monitored at 5, 7, and 10 days postinoculation. Results include the sample size and the mean \pm standard error of the mean. An asterisk represents $P$ values $<0.005$ and two asterisks represent $P$ values $<0.0005$. The $P$ values were calculated using the alternate Welch $t$ test with two-tailed $P$ value. Note that the $P$ value cannot be calculated for the data with a standard deviation of zero. roots were inoculated with R7A or R7A $\Delta$ nodZ. At week 3 postinoculation, R7A had formed effective nodules on complemented hairy roots of $71 \%$ of $n f r l$ mutant plants (25 of 35 plants), whereas R7A $\Delta$ nodZ formed nodules on only $7 \%$ (3 of 46) of plants with complemented hairy roots. In contrast, R7A formed nodules on approximately 65\% (11 of 17 plants) and R7A $\Delta$ nodZ on $42 \%$ (11 of 26 plants) of the complemented $n f r 5$ plants. In comparison, strain R7A induced effective nodules on hairy roots of $81 \%$ (17 of 21 ) and R7A $\Delta$ nodZ on $70 \%$ (21 of 30) of wild-type L. japonicus plants transformed with the empty hairy root transformation vector pAR12.

Histochemical staining of L. japonicus Nin-GUS roots demonstrated that R7A induced Nin expression within 24 h postinoculation and the expression was strongest 10 days postinoculation (Fig. 4). In contrast, induction of Nin expression by R7A $\Delta$ nolL and R7A $\Delta$ nodZ was not observed until 10 days postinoculation and the level of expression was markedly reduced compared with R7A. The zone of expression was essentially limited to the site of nodule primordium development for both mutants, whereas R7A-induced expression was dispersed throughout the root (Fig. 4B). Taken together, these results suggest that the acetylfucose moiety is involved in attaining optimal NF signal transduction initiated by the NFR1/NFR5 receptors.

\section{Determination of NF structures formed by the $M$. loti wild-type and $\triangle n o d Z, \Delta n o l L$, and $\Delta$ nodS $\Delta$ nolO mutants.}

To demonstrate that the observed nodulation behavior of the M. loti $\Delta$ nodZ, $\Delta$ nolL, and $\triangle$ nodS $\triangle$ nolO mutants was related to the anticipated alterations in their NF structures, the NF from R7A and the mutants were extracted, isolated, and identified using mass spectrometry. The results of analysis of the NF are summarized in Table 3.

R7A produced a range of pentameric NF bearing a fatty acyl group on the nonreducing terminal residue; the acyl groups were saturated or monounsaturated and mainly had 16 or 18 carbon atoms, although two structures were proposed to bear a hydroxylated C22 fatty acyl chain. The majority of the observed structures were assigned as being $N$-methylated, consistent with previous reports of NF structures from $M$. loti strains (López-Lara et al. 1995; Niwa et al. 2001), although it is formally possible that these may be unmethylated species bearing unusual fatty acyl chains with an additional $\mathrm{CH}_{2}$ moiety and, thus, having an odd number of carbon atoms (these formal possibilities have not been included in the summary table, for

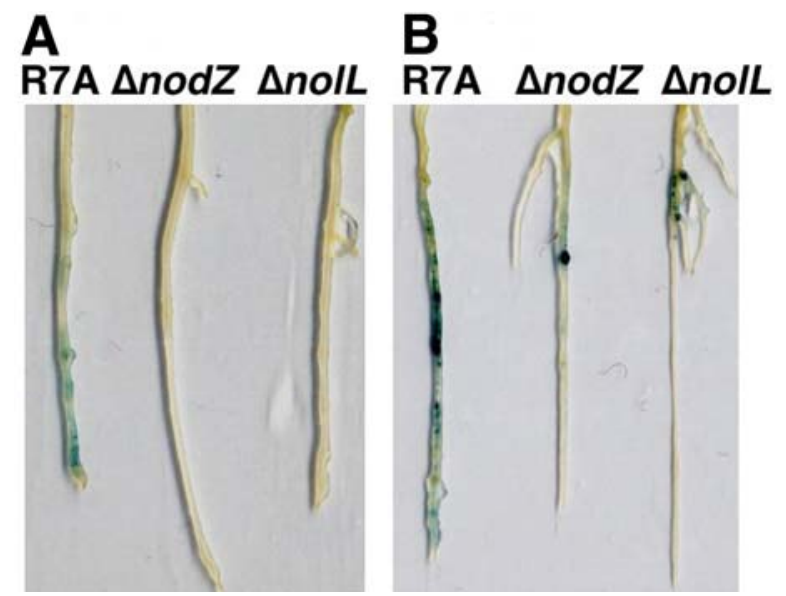

Fig. 4. Histochemical staining of Lotus japonicus Nin-GUS roots after inoculation with R7A, R7A $\Delta$ nodZ, and R7A $\Delta$ nolL at A, 48 h postinoculation and $\mathbf{B}, 10$ days postinoculation. 
conciseness). Several species were also $O$-carbomoylated on the nonreducing terminal residue. All the wild-type NF structures observed were substituted on the reducing terminal residue with either an $O$-fucosyl or an $O$-acetylfucosyl residue. The proposed structures are in keeping with the NF structures previously characterized in $M$. loti strains (López-Lara et al. 1995; Olsthoorn et al. 1998; Niwa et al. 2001). The elution order of the NF was consistent with the proposed structural assignments (Supplementary Table 1), with retention increasing with increasing length of fatty acyl chain and increasing fatty acyl saturation. NF bearing hydroxylated fatty acids have been reported previously (Olsthoorn et al. 2000) but not in M. loti extracts. The relatively early elution of the proposed hydroxylated NF is consistent with their assignment; it is considerably earlier than would be expected for a nonhydroxylated C22 fatty acylbearing homologue. In the previous study, a McLafferty-type rearrangement was observed on CID, resulting in the elimination of a large part of the fatty acid chain (Olsthoorn et al. 2000). This was not observed in the tandem mass spectrometric analyses of the proposed hydroxylated NF in this study

Table 3. Summary of Nod-factor structures produced by R7A and selected mutant strains

\begin{tabular}{|c|c|}
\hline Strains & Structures \\
\hline R7A & $\begin{array}{l}\text { V(C16:0, AcFuc) } \\
\text { V(C16:0, NMe, Fuc) } \\
\text { V(C16:0, NMe, AcFuc) } \\
\text { V(C16:0, NMe, Cb, AcFuc) } \\
\text { V(C18:0, NMe, AcFuc) } \\
\text { V(C18:0, NMe, Cb, AcFuc) } \\
\text { V(C18:1, NMe, Fuc) } \\
\text { V(C18:1, NMe, AcFuc) } \\
\text { V(C18:1, NMe, Cb, AcFuc) } \\
\text { V(C22:0-OH, NMe, AcFuc) } \\
\text { V(C22:0-OH, NMe, Cb, AcFuc) }\end{array}$ \\
\hline R7A $\Delta$ nolL & $\begin{array}{l}\text { V(C14:2, Cb, Fuc }) \\
\text { V(C14:2, NMe, Cb, AcFuc) or V(C14:1-OH, Cb, } \\
\quad \text { AcFuc) } \\
\text { V(C16:0, NMe, Fuc) or V(C16:1-OH, Fuc }) \\
\text { V(C18:0, NMe, Fuc) or V(C18:1-OH, Fuc) } \\
\text { V(C18:1, AcFuc) } \\
\text { V(C18:1, Cb, Fuc) } \\
\text { V(C18:1, Cb, AcFuc) } \\
\text { V(C18:1, NMe, Fuc) or V(C18:2-OH, Fuc) } \\
\text { V(C18:1-OH, NMe, Fuc) or V(C20:0, Fuc) } \\
\text { V(C18:1, NMe, Cb, Fuc) or V(C20:0, Cb, Fuc) } \\
\text { V(C18:1, Cb, NMe, Fuc) or V(C18:2-OH, Cb, Fuc) } \\
\text { V(C18:0, NMe, Cb, AcFuc) or V(C18:1-OH, Cb, } \\
\text { AcFuc) }\end{array}$ \\
\hline R7A $\Delta \operatorname{nodZ}$ & $\begin{array}{l}\mathrm{V}(\mathrm{C} 16: 0, \mathrm{NMe}) \\
\mathrm{V}(\mathrm{C} 16: 0, \mathrm{NMe}, \mathrm{Cb}) \\
\mathrm{V}(\mathrm{C} 18: 0, \mathrm{NMe}) \text { or } \mathrm{V}(\mathrm{C} 19: 0) \\
\mathrm{V}(\mathrm{C} 18: 0, \mathrm{NMe}, \mathrm{Cb}) \\
\mathrm{V}(\mathrm{C} 18: 1, \mathrm{NMe}) \\
\mathrm{V}(\mathrm{C} 18: 1, \mathrm{NMe}, \mathrm{Cb})\end{array}$ \\
\hline R7A $\triangle$ nodS $\Delta$ nolO & $\begin{array}{l}\text { III(C18:1, Fuc) } \\
\text { IV(C16:0, Fuc) } \\
\text { IV(C18:1, Fuc) } \\
\text { V(C12:1, Cb, Fuc) } \\
\text { V(C12:1, Cb, AcFuc) } \\
\text { V(C14:0, AcFuc) } \\
\text { V(C16:0, AcFuc) } \\
\text { V(C16:1, AcFuc) } \\
\text { V(C16:0-OH, NMe, AcFuc) } \\
\text { V(C18:1) } \\
\text { V(C18:1, Fuc) } \\
\text { V(C18:0, NMe) or V(C18:1-OH) } \\
\text { V(C18:0, AcFuc) } \\
\text { V(C18:0-OH, NMe, AcFuc) } \\
\text { V(C18:1, AcFuc) } \\
\text { V(C18:2-OH, AcFuc) or V(C18:1, NMe, AcFuc) } \\
\text { V(C18:1-OH, AcFuc) or V(C18:0, NMe, AcFuc) }\end{array}$ \\
\hline
\end{tabular}

(data not shown). However, it should be noted that the product ion spectra in the two studies were recorded under different CID regimes and, thus, are not necessarily directly comparable; in this study, the product ion spectra were recorded using high-energy CID whereas low-energy CID was used in the previous study.

As expected, the nodZ mutant produced unfucosylated NF (Table 3). In keeping with the results of the wild-type strain analysis, all the NF structures consisted of a pentameric GlcNAc backbone bearing a fatty acyl group on the nonreducing terminal residue; the length of the acyl chains (C16 and $\mathrm{C} 18$ ) and the presence of $\mathrm{N}$-methylation and $\mathrm{O}$-carbomoylation were all analogous to the results of the wild-type extract analysis. Again, the elution order of the NF was consistent with the proposed structural assignments (Supplementary Table 2).

The nolL mutant produced pentameric NF structures with C14-C18 fatty acyl groups on the nonreducing terminal residue. However, in addition to the expected fucosylated NF, acetyl-fucosylated structures were also unexpectedly detected. Although there were fewer different such acetylfucosyl structures produced by the mutant than the wild type, these were not minor components. The major NF species bore C16 and C18 saturated or monosaturated acyl groups. In addition, two minor, previously unreported C14 fatty acyl-bearing species were also observed (Supplementary Table 3 ).

The NF structures of the R7A $\Delta$ nolOAnodS double-mutant strain mainly consisted of a backbone structure of five GlcNAc residues, together with a single three-GlcNAc-residue NF and two GlcNAc4 structures. The NF from the R7A double-mutant strain mostly bore $\mathrm{O}$-acetyl-fucose or $\mathrm{O}$-fucose on the reducing terminal residue, and the nonreducing terminal residue was N-acylated with predominantly C16:0, C16:1, C18:0. or C18:1 chains. Due to the deletion of nolO which is responsible for carbamoylation and $\operatorname{nod} S$ for $\mathrm{N}$-methylation of the NF, this strain was not expected to produce carbamoyl and N-methyl decorations. However, the mass spectrometric and CID tandem mass spectrometric data demonstrated the presence of two very minor carbamoylated species (Supplementary Table 4). However, these species were not detected in NF preparations from the nolO single mutant (data not shown).

\section{DISCUSSION}

Mutants in most of the nodulation genes on ICEMlSym ${ }^{\mathrm{R} 7 \mathrm{~A}}$ did not have an overt symbiotic defect. Of the common nod genes, nodA and nodC mutants showed a $\mathrm{Nod}^{-}$phenotype as expected but, surprisingly, the nodB mutant retained the ability to induce nodules on all Lotus spp., although it was severely compromised in nodulation competition studies. NodB is a deacetylase that removes the $\mathrm{N}$-acetyl moiety from the NF nonreducing terminal residue to allow the addition of an acyl chain to the nitrogen of the resulting primary amine by NodA (John et al. 1993). In most rhizobia, nodABC form an operon and the nodBC genes are phylogenetically congruent whereas, in $M$. loti, $\operatorname{nodB}$ is in a separate operon to $\operatorname{nod} A C$ (Scott et al. 1996; Sullivan et al. 2002) and $\operatorname{nodB}$ and $\operatorname{nod} C$ are phylogenetically incongruent (Wernegreen and Riley 1999). It seems possible that $\operatorname{nod} B$ mutants examined previously were $\mathrm{Nod}^{-}$ because of polar effects on the expression of nodC. Our results suggest that other deacetylases may substitute for the role of NodB, allowing sufficient NF to be made to induce nodulation. Mutants in the regulatory nodD1 and nodD2 genes were $\mathrm{Nod}^{+}$ but nodulation was abolished in the nodD1nodD2 double mutant, indicating that NodD1 and NodD2 can functionally complement one another. However, the nodD1 mutant showed delayed nodulation on Lotus spp. (this work) and is unable to nodulate Leucaena leucocephala (Hubber et al. 2007), indicat- 
ing that nodD1 is the more important of the two nodD genes. No role for nodD2 was apparent.

Chemical substituents on the nonreducing terminal residues of NF are important for the initiation and extension of infection threads in $S$. meliloti and R. leguminosarum (Downie and Surin 1990; Ardourel et al. 1994; Walker and Downie 2000). However M. loti $\Delta$ nodS, $\Delta$ nolO, and $\Delta$ nodS $\Delta$ nolO mutants all nodulated normally and did not display competitive defects in coinoculation studies. NF structures from the $\Delta$ nodS $\Delta$ nolO mutant revealed that only NF species with an atypical fatty acid (C12) carried a carbomoyl group, which may reflect the activity at a very low level of another transferase. Carbomoyl groups were not detected in NF with $\mathrm{C} 16$ or $\mathrm{C} 18$ fatty acids or in NF from the single $\Delta$ nolO mutant, suggesting that the carbomoyl group is not required for the host-specificity or efficiency of nodulation of Lotus spp. The importance of the methyl group in nodulation is still unclear because these NF structural analyses did not distinguish between, for example, $N$-methylated C18:0 or the (less likely) unmethylated C19:0 NF.

Pacios-Bras and associates (2000) showed that the addition of nodZ and nolL to $R$. leguminosarum resulted in a strain, strain DZL, able to nodulate Lotus japonicus, again suggesting a low-stringency requirement for the nonreducing terminal decorations. However, strain DZL is unable to nodulate L. filicaulis, a host-specific nodulation phenotype that has been delimited to differences in the $N f r 5$ receptor genes of $L$. japonicus and $L$. filicaulis (Radutoiu et al. 2007). The NF produced by strain DZL differ from those produced by $M$. loti R7A not only in the decorations on the nonreducing terminal residue but also in the nature of the attached fatty acid. Given that the nonreducingterminal carbamoylation decoration is not required for NF perception by L. filicaulis, our results suggest that the fatty acid may be the more important host-specific determinant.

As expected, strain R7A $\Delta$ nodZ produced NF species lacking the acetylfucose on the reducing terminal residue. Thus, the symbiotic defects induced by R7A $\Delta$ nodZ indicate the importance of the acetylfucose in early symbiotic interactions. Surprisingly, NF from R7A $\Delta$ noll were a mixture of fucosylated $\mathrm{NF}$ and acetylfucosylated NF species, indicating that other acetyltransferases can functionally complement the NolL enzyme. Acetylated structures were also seen in NF species produced by another M. loti nolL mutant (Shibata et al. 2005). However, the fucosylated NF species were more common in R7A $\Delta$ noll than in R7A. The symbiotic phenotypes of R7A $\Delta$ nolL may be the result of a reduced level of acetylfucosylated NF species, or possibly the acetyl group may influence the stability and, hence, concentration of the NF signal. It has previously been suggested that the yield of NF obtained from the $R$. leguminosarum DZL strain was higher than that obtained for $R$. leguminosarum DZ that lacks nolL (Pacios-Bras et al. 2000).

The host-specific nodulation phenotype induced by R7A $\Delta$ nodZ and R7A $\Delta$ nolL on four Lotus spp. may reflect the diversity of plant receptor structures or differences in the sensitivity of the receptors to NF. The ability of both the R7A $\Delta$ nodZ and R7A $\Delta$ nolL mutants to induce root hair curling on $L$. corniculatus and $L$. japonicus plants indicates that the acetylfucose was not required for this early response. The delayed formation of nodule primordia on roots of $L$. filicaulis suggests that the acetylfucose facilitated, but was not an absolute requirement for, the induction of cortical cell division. Strains R7A $\Delta$ nodZ and R7A $\Delta$ nolL exhibited a significantly reduced capacity to elicit infection thread formation on both $L$. japonicus and L. corniculatus. Aberrant infection threads were not observed, suggesting that there was no defect in infection thread extension and maintenance. In contrast, aberrant infection thread structures were observed with S. meliloti nodFnodL mutants that produce NF with modified nonreducing terminal residues (Ardourel et al. 1994; Limpens et al. 2003) and $S$. meliloti exo mutants that produce altered succinoglycans (Cheng and Walker 1998; Pellock et al. 2000). The delayed and reduced infection thread initiation observed with R7A $\Delta$ nodZ and R7A $\Delta$ nolL is consistent with the delayed and reduced nodulation phenotypes and impaired competitiveness of the mutants. Taken together, these results indicate that the acetylfucose moiety on the reducing terminal residue of the $M$. loti NF plays a significant role at the stage of infection thread initiation and rhizobial entry into the root hairs. In the case of L. japonicus, sufficient signaling eventually occurs to allow infection and effective nodule formation whereas, in L. corniculatus and L. filicaulis, signaling does not reach the threshold required to allow bacterial entry.

The in planta complementation experiment showed that introduction of $N f r l$ and $N f r 5$ to nonnodulating L. japonicus $n f r l$ and $n f r 5$ plant mutants, respectively, restored the nodulating ability of the composite plants when inoculated with R7A, as previously reported (Radutoiu et al. 2007). However, nodulation of the $n f r l$ plants transformed with $N f r l$ and inoculated with R7A $\Delta$ nodZ was severely impaired. These results are in accordance with results obtained using the $R$. leguminosarum DZL strain (Radutoiu et al. 2007) and suggest that perception of modified NF is particularly sensitive to Nfrl expression levels or NFR1-mediated signaling. The receptor function obtained was sufficient to allow a normal response to complete NF but not to NF lacking the acetylfucose, providing further evidence that the acetylfucose on the reducing terminal residue of NF is required for efficient signal transduction mediated by NF perception at the extracellular domain of the NFR1 receptor.

The acetylfucose NF decoration also strongly influenced the induction of L. japonicus Nin expression, as shown by histochemical staining. Nin mutants are devoid of infection thread and nodule primordium formation and, consistent with this, reduced Nin expression was observed in L. japonicus Nin-GUS nodule primordia induced by the mutants. Indeed, the expression pattern induced by R7A $\Delta$ nodZ was localized to the site of nodule primordium development whereas Nin expression induced by R7A was dispersed along the plant roots. The reason for this differential expression pattern of L. japonicus Nin induced by different NF structures may again be linked to the efficiency or magnitude of NF signal transmission between cells. The expression of $\mathrm{Nin}$ is dependent on the $\mathrm{Ca}^{2+}$-calmodulin dependent kinase that is presumed to be activated by $\mathrm{Ca}^{2+}$ oscillation (Oldroyd and Downie 2004; Marsh et al. 2007). Higher concentrations of NF with altered structures compared with NF with wild-type structures were required to provoke $\mathrm{Ca}^{2+}$ spiking in Medicago truncatula. For example, S. meliloti NF lacking a sulfate group on the reducing terminal residue had a 30,000-fold-reduced capacity to induce $\mathrm{Ca}^{2+}$ spiking, and NF containing a modified acyl chain showed a 100-fold reduction in activity (Oldroyd et al. 2001; Wais et al. 2002). It is possible that the NF lacking the acetylfucose group produced by strain R7A $\Delta$ nodZ are required at a higher concentration to trigger signal transduction to the same level as that triggered by wild-type NF. The localized expression of Nin in the nodule primordia at 10 days postinoculation may be explained by a weaker signal transduction or reduced infection that is limiting Nin expression in the epidermal cell layer at earlier time points.

Two models have been proposed to explain the perception of $\mathrm{NF}$ that leads to the induction of the NF signal transduction cascade. Ardourel and associates (1994) suggested a two-receptor model, with a signaling receptor responsible for the induction of plant responses leading to the formation of nodule primordia and an entry receptor responsible for the regulation 
of bacterial entry (infection thread formation). The signaling receptor is proposed to have a minimal requirement for $\mathrm{NF}$ structure whereas the entry receptor requires specific NF decorations. A one-receptor model was proposed by Oldroyd and associates (2001), with differential activation of the receptor or receptor complex having different effects on the downstream signaling cascade, resulting in the different stringencies that are observed between early plant responses and bacterial infection. Our study shows that R7A $\Delta$ nodZ was able to induce root hair curling and cortical cell division with only a delay but was severely defective in infection thread formation. These results are consistent with a two-phase recognition model, with early plant responses resulting from low-stringency recognition and rhizobial invasion requiring more stringent recognition. Our data also suggest that the NFR1/NFR5 receptors respond most efficiently to NF containing the acetylfucose residue, consistent with a single-receptor complex with two output phases.

\section{MATERIALS AND METHODS}

Bacterial strains and Lotus spp. seed.

Mesorhizobium loti R7A (Sullivan et al. 1995) was used as the wild-type strain and for generation of all mutants. Strain R7AnifA1:: $\Omega$ kan was described by Sullivan and associates (2001). Seed of L. filicaulis, L. burttii, and L. japonicus Gifu was provided by N. Sandal, University of Aarhus, Denmark. $L$. corniculatus seed was supplied by AgResearch, New Zealand.

\section{Media and growth conditions.}

$M$. loti strains were grown at $28^{\circ} \mathrm{C}$ in or on Rhizobium defined medium (RDM) with either $4 \%$ (wt/vol) glucose (G/RDM) or $5 \%(\mathrm{wt} / \mathrm{vol})$ sucrose (S/RDM) (Sullivan et al. 2001) or in B medium (van Brussel et al. 1977). Media were supplemented with antibiotics as required at the following concentrations: neomycin at $200 \mu \mathrm{g} / \mathrm{ml}$, gentamicin at $40 \mu \mathrm{g} / \mathrm{ml}$, and spectinomycin at $250 \mu \mathrm{g} / \mathrm{ml}$.

\section{Construction of $M$. loti mutants.}

All nod gene mutants were constructed as in-frame markerless deletions. Oligonucleotide primer pairs were designed to amplify two 1 - to $1.2-\mathrm{kb}$ regions, one of which contained a short region of the $5^{\prime}$ end of the gene and approximately $1 \mathrm{~kb}$ of preceding sequence and the other a short region of the $3^{\prime}$ end and $1 \mathrm{~kb}$ of downstream sequence. Restriction endonuclease sites were incorporated into the primers to facilitate directional cloning. The two polymerase chain reaction (PCR) products were cloned into pJQ200SK (Quandt and Hynes 1993) such that the PCR products were fused in appropriate orientation to produce an insert containing an in-frame deletion derivative of the gene and flanking regions. The resulting constructs were confirmed by sequencing and then transferred from Escherichia

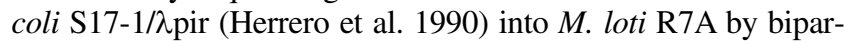
ental spot matings (Hubber et al. 2004). Exconjugants were plated onto G/RDM containing gentamicin and single crossover events were confirmed by PCR. Suitable gentamicin-resistant isolates were then plated on S/RDM and resulting sucrose-resistant, gentamicin-sensitive colonies were screened by PCR and DNA sequencing to confirm the mutants.

\section{Plasmid constructs.}

To construct plasmids pPR1 and pPR2, oligonucleotide primer pairs were designed to amplify the nodZ operon that contains the nodZ, nolK, and noeL genes or the nolL gene and their respective promoter regions. Restriction endonuclease sites were incorporated into each end of the PCR products. The nodZ operon PCR product and the nolL PCR product were ligated into pBluescript II KS and pLitmus28 (New England BioLabs, Bev- erly, MA, U.S.A.), respectively. The inserted fragments were then excised and ligated into pFAJ1700 (Dombrecht et al. 2001) to give pPR1 and pPR2. To produce pJS01, the nodA gene and preceding promoter region was amplified and cloned into pFAJ1700. Plasmid pPR3 was constructed by inserting a 336-bp PCR product amplified from the $n p t I I$ promoter within plasmid pFAJ1708 (Dombrecht et al. 2001) into pPROBE-KT (Miller et al. 2000) as a HindIII-EcoRI fragment upstream of the gfp gene. All plasmid inserts were confirmed by se quencing.

\section{Nodulation assays.}

Lotus spp. seed were scarified by immersion in sulfuric acid for $5 \mathrm{~min}$ followed by washing in sterile water. The seed were then surface-sterilized by immersion in $10 \%$ (vol/vol) commercial bleach and $0.02 \%$ (vol/vol) Tween 80 for $20 \mathrm{~min}$ and washed five times in sterile water. Seed were germinated in the dark for 2 days on $0.8 \%$ (wt/vol) water agar. For nodulation tests, seedlings were grown individually in test tubes containing 8-ml slopes of Jensen's agar (Vincent 1970) capped with foam plugs that allowed unimpeded gas exchange, and left to grow for 2 days prior to inoculation. The plants were observed for nodule formation every 2 days for at least 28 days. In all, 15 to 20 plants were assessed per experiment. The experiments were repeated two to three times. For infection thread assays, seedlings were grown between nylon pillows as previously described (Szczyglowski et al. 1998) with some modifications. The pillows $(5$ by 5 by $19 \mathrm{~cm})$ were soaked in Hoaglund's nitrogen-free medium (Hotter and Scott 1991) for $30 \mathrm{~min}$ before planting. Seedlings were left to grow for 2 days before inoculation. Roots were stained with propidium iodide at 10 $\mu \mathrm{g} / \mathrm{ml}$ and observed using an Olympus BX51 microscope with fluorescence illuminator (BX-RFA) at days 5, 7, and 10 postinoculation. GFP-labeled bacterial cells were visualized using a fluorescence mirror unit (U-MWIB3). For root hair deformation assays, plants were grown on a Fahraeus slide (Vincent 1970) with some modifications. Hoaglund's medium was used and the coverslip was removed from the slide after the agar was set on the Fahraeus slides. Inoculum was spotted at the tip of the root. Root hair deformation was observed under a light microscope at 3 days postinoculation. Ten plant roots were assessed at each time point per assay for each treatment. The assays were repeated twice.

\section{Coinoculation studies.}

These were performed as previously described (Hubber et al. 2004) with some modifications. Plants were inoculated with $200 \mu \mathrm{l}$ of 1:1 mixed suspensions of R7AnifAl:: $\Omega \mathrm{kan}$ and R7A or R7A $\Delta$ nodZ or R7A $\Delta$ noll, each at $10^{3} \mathrm{CFU} / \mathrm{ml}$. Bacteria were isolated from all nodules formed on Lotus plants and were cultured on G/RDM plates. To determine the ratio of different M. loti strains, 10 bacterial colonies from each plate were patched onto nonselective G/RDM and G/RDM containing neomycin at $200 \mu \mathrm{g} / \mathrm{ml}$.

\section{Hairy root transformation and nodulation tests of composite plants.}

$L$ japonicus $n f r l$ and $n f r 5$ mutant complementation studies were performed as previously described (Radutoiu et al. 2007), except that composite plants were analyzed for nodulation at 3 weeks postinoculation.

\section{NF purification.}

Plasmid pMP2112 (Spaink et al. 1989) that contains the nodD gene of $R$. leguminosarum was transferred to the rele vant strain so that nod gene expression could be induced with naringenin (López-Lara et al. 1995). NF were extracted using $n$-butanol as described (Niwa et al. 2001). The crude NF ex tracts were pre- 
fractionated using solid-phase extraction (SPE) on a C18 column (Strata C18-E 70A), essentially as described (Soria-Díaz et al. 2003). The NF were eluted from the SPE columns using sequentially two different aqueous acetonitrile [ACN (aq)] solutions (45 and $60 \%, \mathrm{vol} / \mathrm{vol}$ ) to produce two fractions, which were then dried under vacuum. The SPE fractions were reconstituted overnight in $700 \mu \mathrm{l}$ of $60 \%$ ACN (aq). This was diluted with $\mathrm{H}_{2} \mathrm{O}$ to a final volume of $2 \mathrm{ml}$ prior to reversed-phase highperformance liquid chromatography (HPLC) fractionation. The HPLC fractionation was carried out on a C18 column $(5 \mu \mathrm{m}$ OSD2, 4.6 by $250 \mathrm{~mm}$ ) with two subsequent $1-\mathrm{ml}$ injections, and eluted using a gradient elution of $20 \% \mathrm{ACN}(\mathrm{aq})$ for $20 \mathrm{~min}$ and 20 to $60 \%$ ACN (aq) for $20 \mathrm{~min}$ flowing at $1 \mathrm{ml} \mathrm{min}{ }^{-1}$. The column was washed and reequilibrated with $90 \% \mathrm{ACN}$ (aq) for 5 min and $20 \% \mathrm{ACN}(\mathrm{aq})$ for 5 min. During the gradient, 1-min fractions were collected. Fractions corresponding to peaks in the UV absorbance were pooled, dried under vacuum, and reconstituted in $100 \mu \mathrm{l}$ of $\mathrm{ACN}: \mathrm{H}_{2} \mathrm{O}(1: 1 \mathrm{vol} / \mathrm{vol})$ before mass spectrometric analysis.

\section{Mass spectrometric analysis.}

Matrix-assisted laser desorption-ionization mass spectrometry (MALDI-MS) and tandem mass spectrometry (MS/MS) spectra were recorded using an Applied Biosystems 4700 proteomics analyzer with time-of-flight/time-of-flight optics. The HPLC fraction $(0.5 \mu \mathrm{l})$ was mixed with an equal volume of the matrix solution, $\alpha$-cyano-4-hydroxy-cinnamic acid at $7 \mathrm{mg} / \mathrm{ml}$, before being spotted on a MALDI target plate. Mass spectra were recorded over the range $m / z, 800$ to 4,000 , with a "focus mass" of $\mathrm{m} / \mathrm{z}, 1,500$ using the 4700 Explorer software. The laser was set at an intensity of 5,000 units; each spectrum was acquired using 1,000 laser shots in total, made up of $20 \mathrm{sub}$ spectra, each of which consisted of 50 laser shots. MS/MS spectra were acquired with an average of 2,500 laser shots per spectrum. The collision energy was set at $1 \mathrm{keV}$ and the ions were collided in the CID cell with nitrogen as the collision gas.

Additional data were obtained on some fractions and structures using the same matrix and spot preparation method, recording the MALDI MS and MS/MS data using a Bruker ultraflex III mass spectrometer with LIFT-MS/MS facility (Centre of Excellence in Mass Spectrometry, University of York). Mass spectra were obtained in the range $\mathrm{m} / \mathrm{z}, 500$ to 3,000, using the FlexControl software; each spectrum was acquired manually, and involved the summing of laser shots (up to 4,000) in order to generate spectra of an acceptable signalto-noise ratio. MS/MS spectra were obtained on precursor ions accelerated to $8 \mathrm{kV}$ and selected in the timed ion gate. Fragment ions produced on laser-induced dissociation were accelerated using a further 18 to $20 \mathrm{kV}$ in the LIFT cell, and separated in the reflectron; metastable ion suppression was used during acquisition of the fragment ions.

\section{ACKNOWLEDGMENTS}

This work was supported by grants from the Marsden Fund administered by the Royal Society of New Zealand and the Danish National Research Foundation. P. Rodpothong thanks the European Molecular Biology Organization for a short-term fellowship and the Department of Microbiology, University of Otago for a Ph.D. scholarship. We thank N. Sandal for his generous supply of Lotus seed and R. Easingwood and the Electron Microscopy Unit, University of Otago, for assistance with the transmission electron microscopy work. D. Sumpton's studentship was supported by the Eengineering and Physical Sciences Research Council U.K. (EPSRC) and the European Union (ICA4-CT-2001-10056), K. Songsrirote is grateful for Ph.D. support via a Royal Thai Scholarship, and J. Thomas-Oates gratefully acknowledges funding from the Analytical Chemistry Trust Fund, the RSC Analytical Division, and EPSRC. The Centre of Excellence in Mass Spectrometry at York is supported by Science City York and Yorkshire Forward using funds from the Northern Way Initiative.

\section{LITERATURE CITED}

Amor, B. B., Shaw, S. L., Oldroyd, G. E., Maillet, F., Penmetsa, R. V., Cook, D., Long, S. R., Dénarié, J., and Gough, C. 2003. The NFP locus of Medicago truncatula controls an early step of Nod factor signal transduction upstream of a rapid calcium flux and root hair deformation. Plant J. 34:495-506.

Ardourel, M., Demont, N., Debellé, F., Maillet, F., de Billy, F., Promé, J., Dénarié, J., and Truchet, G. 1994. Rhizobium meliloti lipooligosaccharide nodulation factors: Different structural requirements for bacterial entry into target root hair cells and induction of plant symbiotic development responses. Plant Cell 6:1357-1374.

Berck, S., Perret, X., Quesada-Vincens, D., Promé, J. C., Broughton, W. J., and Jabbouri, S. 1999. NolL of Rhizobium sp. strain NGR234 is required for O-acetyltransferase activity. J. Bacteriol. 181:957-964.

Cheng, H. P., and Walker, G. C. 1998. Succinoglycan is required for initiation and elongation of infection threads during nodulation of alfalfa by Rhizobium meliloti. J. Bacteriol. 180:5183-91.

Corvera, A., Promé, D., Promé, J. C., Martínez-Romero, E., and Romero, D. 1999. The nolL gene from Rhizobium etli determines nodulation efficiency by mediating the acetylation of the fucosyl residue in the nodulation factor. Mol. Plant-Microbe Interact. 13:236-246.

Dombrecht, B., Vanderleyden, J., and Michiels, J. 2001. Stable RK2-derived cloning vectors for the analysis of gene expression and gene function in gram-negative bacteria. Mol. Plant-Microbe Interact. 14:426-430.

Downie, J. A., and Surin, B. P. 1990. Either of two nod gene loci can complement the nodulation defect of a nod deletion mutant of Rhizobium leguminosarum biovar viciae. Mol. Gen. Genet. 222:81-86.

Fisher, R. F., and Long, S. R. 1993. Interaction of NodD at the nod box: NodD binds to two distinct sites on the same face of the helix and induces a bend in the DNA. J. Mol. Biol. 233:336-348.

Geurts, R., Fedorova, E., and Bisseling, T. 2005. Nod factor signaling genes and their function in the early stages of Rhizobium infection. Curr. Opin. Plant Biol. 8:346-352.

Hayashi, M., Miyahara, A., Sato, S., Kato, T., Yoshikawa, M., Taketa, M., Hayashi, M., Pedrosa, A., Onda, R., Imaizumi-Anraku, H., Bachmair, A., Sandal, N., Stougaard, J., Murooka, Y., Tabata, S., Kawasaki, S., Kawaguchi, M., and Harada, K. 2001. Construction of a genetic linkage map of the model legume Lotus japonicus using an intraspecific F2 population. DNA Res. 8:301-310.

Herrero, M., de Lorenzo, V., and Timmis, K. N. 1990. Transposon vectors containing stable non-antibiotic resistance selection markers for cloning and stable chromosomal insertion of foreign genes in gram-negative bacteria. J. Bacteriol. 172:6557-6567.

Hotter, G. S., and Scott, D. B. 1991. Exopolysaccharide mutants of Rhizobium loti are fully effective on a determinate nodulating host but are ineffective on an indeterminate nodulating host. J. Bacteriol. 173:851859.

Hubber, A., Vergunst, A. C., Sullivan, J. T., Hooykaas, P. J. J., and Ronson, C. W. 2004. Symbiotic phenotypes and translocated effector proteins of the Mesorhizobium loti strain R7A VirB/D4 type IV secretion system. Mol. Microbiol. 54:561-574.

Hubber, A., Sullivan, J. T., and Ronson, C. W. 2007. Symbiosis-induced cascade regulation of the Mesorhizobium loti R7A VirB/D4 type IV secretion system. Mol. Plant-Microbe Interact. 20:255-261.

John, M., Rohrig, H., Schmidt, J., Wieneke, U., and Schell, J. 1993. Rhizobium NodB protein involved in nodulation signal synthesis is a chitooligosaccharide deacetylase. Proc. Natl. Acad. Sci. U.S.A. 90:625-629.

Kawaguchi, M., Pedrosa, A., Yano, K., Hayashi, M., Murooka, Y., Saito, K., Nagata, T., Namai, K., Nishida, H., Shibata, D., Sato, S., Tabata, S., Hayashi, M., Harada, K., Sandal, N., Stougaard, J., Bachmair, A., and Grant, W. F. 2005. Lotus burttii takes a position of the third corner in the Lotus molecular genetics triangle. DNA Res. 12:69-77.

Limpens, E., Franken, C., Smit, P., Willemse, J., Bisseling, T., and Geurts, R. 2003. LysM domain receptor kinases regulating rhizobial Nod factor-induced infection. Science 302:630-633.

López-Lara, I. M., van den Berg, J. D. J., Thomas-Oates, J. E., Glushka, J., Lugtenberg, B. J., and Spaink, H. P. 1995. Structural identification of the lipo-chitin oligosaccharide nodulation signals of Rhizobium loti. Mol. Microbiol. 15:627-638.

López-Lara, I. M., Blok-Tip, L., Quinto, C., Garcia, M. L., Stacey, G., Bloemberg, G. V., Lamers, G. E. M., Lugtenberg, B. J. J., ThomasOates, J. E., and Spaink, H. P. 1996. NodZ of Bradyrhizobium extends the nodulation host range of Rhizobium by adding a fucosyl residue to nodulation signals. Mol. Microbiol. 21:397-408.

Madsen, E. B., Madsen, L. H., Radutoiu, S., Olbryt, M., Rakwalska, M., Szczyglowski, K., Sato, S., Kaneko, T., Tabata, S., Sandal, N., and Stougaard, J. 2003. A receptor kinase gene of the LysM type is involved in legume perception of rhizobial signals. Nature 425:637-640. 
Marsh, J. F., Rakocevic, A., Mitra, R. M., Brocard, L., Sun, J., Eschstruth, A., Long, S. R., Schultze, M., Ratet, P., and Oldroyd, G. E. 2007. Medicago truncatula NIN is essential for rhizobial-independent nodule organogenesis induced by autoactive calcium/calmodulin-dependent protein kinase. Plant Physiol. 144:324-335.

Mergaert, P., D’Haeze, W., Fernández-López, M., Geelen, D., Goethals, K., Promé, J. C., Van Montagu, M., and Holsters, M. 1996. Fucosylation and arabinosylation of Nod factors in Azorhizobium caulinodans: Involvement of nolK, nodZ as well as noe $C$ and/or downstream genes. Mol. Microbiol. 21:409-419.

Miller, W. G., Leveau, J. H., and Lindow, S. E. 2000. Improved gfp and inaZ broad-host-range promoter-probe vectors. Mol. Plant-Microbe Interact. 13:1243-1250.

Niwa, S., Kawaguchi, M., Imazumi-Anraku, H., Chechetka, S. A., Ishizaka, M., Ikuta, A., and Kouchi, H. 2001. Responses of a model legume Lotus japonicus to lipochitin oligosaccharide nodulation factors purified from Mesorhizobium loti JRL501. Mol. Plant-Microbe Interact. 14:848-856.

Oldroyd, G. E., and Downie, J. A. 2004. Calcium, kinases and nodulation signaling in legumes. Nature Rev. Mol. Cell Biol. 5:566-576.

Oldroyd, G. E., and Downie, J. A. 2008. Coordinating nodule morphogenesis with rhizobial infection in legumes. Annu. Rev. Plant Biol. 59:519-546

Oldroyd, G. E., Mitra, R. M., Wais, R., and Long, S. R. 2001. Evidence for structurally specific negative feedback in the Nod factor signal transduction pathway. Plant J. 28:191-199.

Olsthoorn, M. M., López-Lara, I. M., Petersen, B. O., Bock, K., Haverkamp, J., Spaink, H. P., and Thomas-Oates, J. E. 1998. Novel branched Nod factor structure results from alpha- $(1 \rightarrow 3)$ fucosyl transferase activity: The major lipo-chitin oligosaccharides from Mesorhizobium loti strain NZP2213 bear an alpha- $(1 \rightarrow 3)$ fucosyl substituent on a nonterminal backbone residue. Biochemistry 37:9024-9032.

Olsthoorn, M. M., Stokvis, E., Haverkamp, J., Spaink, H. P., and ThomasOates, J. E. 2000. Growth temperature regulation of host-specific modifications of rhizobial lipo-chitin oligosaccharides: The function of $\operatorname{nodX}$ is temperature regulated. Mol. Plant-Microbe Interact. 13:808-820.

Pacios-Bras, C., Jordá, M. A., Wijfjes, A. H. M., Harteveld, M., Stuurman, N., Thomas-Oates, J. E., and Spaink, H. P. 2000. A Lotus japonicus nodulation system based on heterologous expression of the fucosyl transferase NodZ and the acetyl transferase NolL in Rhizobium leguminosarum. Mol. Plant-Microbe Interact. 13:475-479.

Pellock, B. J., Cheng, H. P., and Walker, G. C. 2000. Alfalfa root nodule invasion efficiency is dependent on Sinorhizobium meliloti polysaccharides. J. Bacteriol. 182:4310-4318.

Quandt, J., and Hynes, F. M. 1993. Versatile suicide vectors which allow direct selection for gene replacement in gram-negative bacteria. Gene 127:15-21.

Quesada-Vincens, D., Fellay, R., Nasim, T., Viprey, V., Burger, U., Promé, J. C., Broughton, W. J., and Jabbouri, S. 1997. Rhizobium sp. strain NGR234 NodZ protein is a fucosyltransferase. J. Bacteriol. 179:50875093.

Radutoiu, S., Madsen, L. H., Madsen, E. B., Felle, H. H., Umehara, Y., Gronlund, M., Sato, S., Nakamura, Y., Tabata, S., Sandal, N., and Stougaard, J. 2003. Plant recognition of symbiotic bacteria requires two LysM receptor-like kinases. Nature 425:585-592.

Radutoiu, S., Madsen, L. H., Madsen, E. B., Jurkiewicz, A., Fukai, E. Quistgaard, M. M., Albrektsen, A. S., James, E. K., Thirup, S., and Stougaard, J. 2007. LysM domains mediate lipochitin-oligosaccharide recognition and $\mathrm{Nfr}$ genes extend the symbiotic host range. EMBO (Eur. Mol. Biol. Organ.) J. 26:3923-3935.

Ramsay, J. P., Sullivan, J. T., Stuart, G. S., Lamont, I. L., and Ronson, C. W. 2006. Excision and transfer of the Mesorhizobium loti R7A symbiosis island requires an integrase IntS, a novel recombination directionality factor RdfS, and a putative relaxase RlxS. Mol. Microbiol. 62:723-734.

Riely, B. K., Mun, J. H., and Ané, J. M. 2006. Unraveling the molecular basis for symbiotic signal transduction in legumes. Mol. Plant Pathol. 7:197-207.

Rostas, K., Kondorosi, E., Horvath, B., Simoncsits, A., and Kondorosi, A. 1986. Conservation of extended promoter regions of nodulation genes in Rhizobium. Proc. Natl. Acad. Sci. U.S.A. 83.
Sandal, N., Petersen, T. R., Murray, J., Umehara, Y., Karas, B., Yano, K. Kumagai, H., Yoshikawa, M., Saito, K., Hayashi, M., Murakami, Y., Wang, X., Hakoyama, T., Imaizumi-Anraku, H., Sato, S., Kato, T., Chen, W., Hossain, M. S., Shibata, S., Wang, T. L., Yokota, K., Larsen, K., Kanamori, N., Madsen, E. B., Radutoiu, S., Madsen, L. H., Radu, T. G., Krusell, L., Ooki, Y., Banba, M., Betti, M., Rispail, N., Skøt, L., Tuck, E., Perry, J., Yoshida, S., Vickers, K., Pike, J., Mulder, L., Charpentier, M., Müller, J., Ohtomo, R., Kojima, T., Ando, S., Marquez, A. J., Gresshoff, P. M., Harada, K., Webb, J., Hata, S., Suganuma, N., Kouchi, H., Kawasaki, S., Tabata, S., Hayashi, M., Parniske, M., Szczyglowski, K., Kawaguchi, M., and Stougaard, J. 2006. Genetics of symbiosis in Lotus japonicus: Recombinant inbred lines, comparative genetic maps, and map position of 35 symbiotic loci. Mol. Plant-Microbe Interact. 19:80-91.

Scott, D. B., Young, C. A., Collins-Emerson, J. M., Terzaghi, E. A., Rockman, E. S., Lewis, P. E., and Pankhurst, C. E. 1996. Novel and complex chromosomal arrangement of Rhizobium loti nodulation genes. Mol. Plant-Microbe Interact. 9:187-197.

Shibata, S., Mitsui, H., and Kouchi, H. 2005. Acetylation of fucosyl residue at the reducing end of Mesorhizobium loti Nod factors is not essential for nodulation of Lotus japonicus. Plant Cell Physiol. 46:1017-1020.

Smit, P., Limpens, E., Geurts, R., Fedorova, E., Dolgikh, E., Gough, C. and Bisseling, T. 2007. Medicago LYK3, an entry receptor in rhizobial nodulation factor signaling. Plant Physiol. 145:183-191.

Soria-Díaz, M. E., Tejero-Mateo, P., Espartero, J. L., Rodriguez-Carvajal, M. A., Moron, B., Sousa, C., Megias, M., Amarger, N., Thomas-Oates, J. E., and Gil-Serrano, A. M. 2003. Structural determination of the lipochitin oligosaccharide nodulation signals produced by Rhizobium giardinii bv. giardinii H152. Carbohydr. Res. 338:237-250.

Spaink, H. P. 2000. Root nodulation and infection factors produced by rhizobial bacteria. Annu. Rev. Microbiol. 54:257-288.

Spaink, H. P., Okker, R. J., Wijffelman, C. A., Tak, T., Goosen-de Roo, L., Pees, E., van Brussel, A. A., and Lugtenberg, B. J. 1989. Symbiotic properties of rhizobia containing a flavonoid-independent hybrid nodD product. J. Bacteriol. 171:4045-4053.

Sullivan, J. T., and Ronson, C. W. 1998. Evolution of rhizobia by acquisition of a 500-kb symbiosis island that integrates into a phe-tRNA gene. Proc. Natl. Acad. Sci. U.S.A. 95:5145-5149.

Sullivan, J. T., Patrick, H. N., Lowther, W. L., Scott, D. B., and Ronson, C. W. 1995. Nodulating strains of Rhizobium loti arise through chromosomal symbiotic gene transfer in the environment. Proc. Natl. Acad. Sci. U.S.A. 92:8985-8989.

Sullivan, J. T., Brown, S. D., Yocum, R. R., and Ronson, C. W. 2001. The bio operon on the acquired symbiosis island of Mesorhizobium $\mathrm{sp}$ strain R7A includes a novel gene involved in pimeloyl-CoA synthesis. Microbiology 147:1315-1322.

Sullivan, J. T., Trzebiatowski, J. R., Cruickshank, R. W., Gouzy, J., Brown, S. D., Elliott, R. M., Fleetwood, D. J., McCallum, N. G., Rossbach, U., Stuart, G. S., Weaver, J. E., Webby, R. J., de Bruijn, F. J., and Ronson, C. W. 2002. Comparative sequence analysis of the symbiosis island of Mesorhizobium loti strain R7A. J. Bacteriol. 184:3086-3095.

Szczyglowski, K., Shaw, R. S., Wopereis, J., Copeland, S., Hamburger, D., Kasiborski, B., Dazzo, F. B., and de Bruijn, F. J. 1998. Nodule organogenesis and symbiotic mutants of the model legume Lotus japonicus. Mol. Plant-Microbe Interact. 11:684-697.

van Brussel, A. A., Planqué, K., and Quispel, A. 1977. The wall of Rhizobium leguminosarum in bacteroid and free-living forms. J. Gen. Microbiol. 101:51-56.

Vincent, J. M. 1970. A Manual for the Practical Study of Root Nodule Bacteria. Blackwell Scientific Publications, Oxford.

Wais, R. J., Keating, D. H., and Long, S. R. 2002. Structure-function analysis of Nod factor-induced root hair calcium spiking in rhizobiumlegume symbiosis. Plant Physiol. 129:211-224.

Walker, S. A., and Downie, J. A. 2000. Entry of Rhizobium leguminosarum bv. viciae into root hairs requires minimal Nod factor specificity, but subsequent infection thread growth requires nodO or nodE. Mol. PlantMicrobe Interact. 13:754-762.

Wernegreen, J. J., and Riley, M. A. 1999. Comparison of the evolutionary dynamics of symbiotic and housekeeping loci: A case for the genetic coherence of rhizobial lineages. Mol. Biol. Evol. 16:98-113. 